\title{
UV radiation effects on pigments, photosynthetic efficiency and DNA of an Antarctic marine benthic diatom community
}

\author{
Angela Wulff ${ }^{1, *}$, Michael Y. Roleda ${ }^{2,4}$, Katharina Zacher ${ }^{3}$, Christian Wiencke ${ }^{3}$ \\ ${ }^{1}$ Marine Ecology, University of Gothenburg, PO Box 461, 40530 Göteborg, Sweden \\ ${ }^{2}$ Institute for Polar Ecology, University of Kiel, Wischhofstrasse 1-3, Building 12, 24148 Kiel, Germany \\ ${ }^{3}$ Alfred Wegener Institute for Polar and Marine Research, Am Handelshafen 12, 27570 Bremerhaven, Germany \\ ${ }^{4}$ Present address: Marine Ecology, University of Gothenburg, PO Box 461, 40530 Göteborg, Sweden
}

\begin{abstract}
The impact of ultraviolet radiation (UVR) on a semi-natural, soft-bottom diatom community from Potter Cove, King Georg Island, Antarctica, was investigated. The objective was to estimate the impact of UV-B (280 to $320 \mathrm{~nm}$ ) and UV-A (320 to $400 \mathrm{~nm}$ ) on photosynthetic efficiency, pigments, DNA damage and repair. The diatom community was exposed to different doses of radiation treatments: PAR + UV-A + UV-B (PAB), PAR + UV-A (PA) and PAR (P). The most frequently observed species were Pleurosigma obscurum and Gyrosigma fasciola. Within the $0.7 \mathrm{~mm}$ substrate, UV radiation significantly reduced the Photosystem II (PS II) maximum efficiency $\left(F_{\mathrm{v}} / F_{\mathrm{m}}\right)$. Complete recovery was observed after $6 \mathrm{~h}$ post-cultivation under dim white light. The accumulation of diatoxanthin increased with exposure time for the P and PA treatments, but not for the PAB treatment, indicating a UV-B-related blocking of the de-epoxidation process within the xanthophyll cycling process. The ratio of diatoxanthin:(diatoxanthin+diadinoxanthin) decreased again to initial values after $24 \mathrm{~h}$ of recovery. The amount of DNA damage, measured as accumulation of cyclobutane pyrimidine dimers (CPDs), was minimal and increased with increasing UV-B dose, but DNA lesions were completely repaired within $24 \mathrm{~h}$ under dim white light. Regardless of possible avoidance strategies, e.g. vertical migration, negative UV treatment effects were observed. However, these effects were transient, facilitated by the dynamic recovery of photoinhibition and an efficient DNA damage repair mechanism. Although results from laboratory experiments using artificial radiation can only be extrapolated to field conditions with great caution, we conclude that Antarctic marine benthic diatoms inoculated into a semi-natural habitat are resilient to unnaturally high UVR.
\end{abstract}

KEY WORDS: Benthic diatoms $\cdot$ UV radiation $\cdot$ UV-B radiation $\cdot$ Xanthophyll pigments $\cdot F_{\mathrm{v}} / F_{\mathrm{m}}$. DNA damage $\cdot$ Microphytobenthos $\cdot P-E$ curve

\section{INTRODUCTION}

Stratospheric ozone depletion over the Antarctic and the consequent increase of ultraviolet-B radiation (UV$\mathrm{B}, 280$ to $315 \mathrm{~nm}$ ) is a threat to all living organisms, and unfortunately little improvement is expected for total column ozone in the Antarctic for decades (Weatherhead \& Andersen 2006). Ultraviolet-A radiation (UV-A, 315 to $400 \mathrm{~nm}$ ) and photosynthetically active radiation (PAR, 400 to $700 \mathrm{~nm}$ ) are involved in photoreactivation and photorepair of the DNA (Karentz 1994 and refer- ences therein). Because ozone depletion results in increased UV-B radiation without a proportional increase in UV-A and PAR, repair mechanisms might be impaired. At Potter Cove, King Georg Island, Antarctica, UV radiation (UVR, 280 to $400 \mathrm{~nm}$ ) can penetrate to $19 \mathrm{~m}$ water depth ( $1 \%$ of the irradiance at the water surface), and could thereby also affect subtidal biota. Although the sediment has been proposed to be a refuge to escape harmful radiation, UVR has been shown to penetrate ca. $0.6 \mathrm{~mm}$ (UV-B) and $1 \mathrm{~mm}$ (UV-A) into a sandy sediment (Wulff et al. 1999). 
In shallow-water areas, benthic microalgae can account for ca. $50 \%$ of the total primary productivity (Underwood \& Kromkamp 1999). The corresponding value for subtidal benthic microalgae on continental shelves was $42 \%$ of the total areal primary productivity (Nelson et al. 1999). They also form an important food source for both benthic and pelagic heterotrophs in Antarctic marine ecosystems, where resuspended benthic diatoms constitute a substantial part of the phytoplankton carbon pool (Ahn et al. 1994, Schloss et al. 1998).

UVR negatively affects benthic microalgae in various ways with a possible cascade effect on the ecosystem altogether (Bothwell et al. 1994). In soft bottom communities, ambient UV-B has been proven to be a stress factor for microbenthos and a selective force during early growth and succession (Wulff et al. 2000). Primary productivity and carbon allocation were strongly affected by both ambient and enhanced levels of UV-B (Sundbäck et al. 1997, Wulff et al. 1999, 2000), but biomass and species composition were not affected (Sundbäck et al. 1997, Wulff et al. 1999, 2008). Responses of microalgal photosynthesis to ambient UV-B vary with substrate type and community density, as well as irradiance levels (Franklin \& Forster 1997, Villafañe et al. 2003). Diatoms can gain protection against excessive irradiance through downregulation of Photosystem II (PS II) efficiency to regulate excitation energy for the photosynthetic process. For light harvesting, the diatom xanthophyll cycle can be used to modulate excessive energy through thermal dissipation by de-epoxidation of diadinoxanthin to diatoxanthin (Olaizola \& Yamamoto 1994, Demmig-Adams \& Adams 1996, van de Poll et al. 2006). The process is reversed in low light when the excessive light energy is reduced.

Production of UV-absorbing compounds is a protective mechanism in Antarctic planktonic centric diatoms (Buma et al. 2006). However, the benthic diatom community almost exclusively consists of pennate diatoms, producing very low, if any, amounts of UV-absorbing compounds (Wulff et al. 1999, Roux et al. 2002). Other strategies to reduce negative effects of excessive radiation including UVR are vertical migration (Underwood et al. 1999, Waring et al. 2007) and, on a community level, 'self-shading', i.e. cells deeper in the assemblages get protection through light absorption by cells at the surface (Blanchard \& Cariou-le Gall 1994).

Our work was prompted by the lack of studies dealing with the response of Antarctic benthic marine microalgae to UVR. The objective was to estimate the short-term (hours) impact of UV-B and UV-A on benthic marine diatoms (photosynthetic efficiency, photosynthetic pigments and DNA damage).

\section{MATERIALS AND METHODS}

The experiments were performed from 3 to 14 December 2004 at Dallmann Laboratory, Potter Cove, King George Island, Antarctica (62 $\left.15^{\prime} \mathrm{S}, 58^{\circ} 41^{\prime} \mathrm{W}\right)$. Fine-grained sandy to silty sediment with brown mats of benthic diatoms were collected from 5 to $7 \mathrm{~m}$ water depth by SCUBA diving. The top layer $(1 \mathrm{~cm})$ was scraped off, and the sediment was brought to the laboratory, gently shaken and sieved (mesh size $500 \mu \mathrm{m}$ ) using GF/F-filtered surface seawater. The sediment was stirred, and the overlying water containing suspended microalgae was transferred to a glass beaker gently bubbled with air and left to grow for ca. $3 \mathrm{wk}$ under dim white light (ca. $10 \mu \mathrm{mol}$ photons $\mathrm{m}^{-2} \mathrm{~s}^{-1}$ ). The overlying water was enriched once a week with macronutrients and micronutrients, corresponding to f/2 medium (Guillard 1975).

Experimental setup and treatments. The experiments were carried out in a temperature-controlled laboratory container at 4 to $6^{\circ} \mathrm{C}$. Each Petri dish $(55 \mathrm{~mm}$ diameter, $\mathrm{n}=3$ to 5 ) was filled with a ca. $0.5 \mathrm{~mm}$ layer of acid-cleaned sand (5 g) and carefully submerged into the bottom of a plastic container with minimal disruption of the sand cover inside the dish. A suspension of microalgae was evenly poured into the water surface of the basin. The clean sand with the diatom suspension on top (and some organic material) together constituted a layer of $<0.7 \mathrm{~mm}$. The suspended diatoms in the water column were allowed to settle into the Petri dishes for ca. 12 h. After settlement, Petri dishes were slowly removed from the bottom of the basin and transferred to the experimental workbench under dim white light $\left(<10 \mu \mathrm{mol}\right.$ photons $\left.\mathrm{m}^{-2} \mathrm{~s}^{-1}\right)$. One setup was designed for testing radiation treatment effects on photosynthetic pigments $(\mathrm{n}=4)$, another setup was used for photosynthetic parameters $(n=5)$ and the third setup was designed to evaluate DNA damage $(\mathrm{n}=3)$ (the different treatments are described below).

Radiation treatments. Background PAR was provided by white fluorescent lamps (Osram, L65 W/25S) with addition of UV lamps (Q-Panel UV-A-340, 40 W), emitting a spectrum qualitatively similar to solar radiation in the range of 295 to $340 \mathrm{~nm}$. Three kinds of filter foils were used to cut off different wavelength ranges from the spectrum emitted by the fluorescent lamps: (1) Ultraphan transparent (Digefra), (2) Folanorm 320 (Folex), and (3) Ultraphan URUV Farblos (Digefra), corresponding to the PAB (280 to $700 \mathrm{~nm}$ ), PA (320 to $700 \mathrm{~nm}$ ) and $\mathrm{P}$ (400 to $700 \mathrm{~nm}$ ) treatments, respectively. The cut-off wavelengths of the available filters differed slightly from the definition of the CIE (Commission Internationale De l'Éclairage; UV-B $=280$ to $315 \mathrm{~nm}$, $\mathrm{UV}-\mathrm{A}=315$ to $400 \mathrm{~nm}$ ). Irradiation in the laboratory was measured below the cut-off filters using a Solar 
Light PMA 2100 radiometer (Solar Light) equipped with a UV-A (PMA 2110) and a UV-B broad-band sensor (PMA 2106, Solar Light). Additional UV-B measurements were made using a Schott WG320 filter (Schott) to exclude wavelengths over $320 \mathrm{~nm}$, as the spectral range of the UV-B sensor extends into the UV-A region of the spectrum. Both filtered and unfiltered intensities are shown in Table 1. PAR was measured using a flat-head LI-COR 190 SA quantum sensor (cosine corrected) connected to a LI-COR LI1400 datalogger (LI-COR Bioscience). Light intensities and doses (PAR, UV-A and UV-B) for the different treatments are shown in Table 1.

Diatom density and species composition. Initial microalgal cell density was estimated in triplicates. The sample was vigorously shaken by hand for $30 \mathrm{~s}$, and after another ca. $30 \mathrm{~s}$ (to allow sand grains to settle), a minimum of 2 individual subsamples $(1 \mathrm{ml})$ of the algal suspension were pipetted into a Sedgewick Rafter counting chamber and counted under a light microscope $\left(20 \times_{i}\right.$ Zeiss, Axiolab). Naphrax-mounted slides were prepared for diatom species identification. Samples were washed with distilled water to remove the salts and then boiled with $30 \% \mathrm{H}_{2} \mathrm{O}_{2}$ to remove organic matter. Subsequently, 1 to 2 drops of $50 \% \mathrm{HCl}$ were added to remove carbonates and to eliminate $\mathrm{H}_{2} \mathrm{O}_{2}$. After washing, diatom suspensions were allowed to settle on a cover slip and left to dry before being mounted. For species identification, differential interference contrast and phase contrast microscopy $(100 \times$ magnification) were used (Axioplan 2 imaging; Zeiss). Diatoms were identified following Hustedt (e.g. 1961), Krammer \& Lange-Bertalot (1986, 1988), Hendey (1952, 1964) and Witkowski et al. (2000). The nomenclature was updated with the help of Round et al. (1990).

Photosynthesis. The effects of UVR on optimum quantum yield of the diatom suspension was determined by measuring the variable chlorophyll fluorescence of PS II (Suggett et al. 2003) by use of a pulse-amplitude modulated fluorometer (Water-PAM, connected to a PC with WIN CONTROL Software; Walz). After $8 \mathrm{~h}$ exposure to the different radiation treatments, followed by $24 \mathrm{~h}$ recovery, the content of the whole Petri dish was transferred into a $20 \mathrm{ml}$ vial, the bottle was shaken for $30 \mathrm{~s}$, the sand grains left to settle for another $30 \mathrm{~s}$, and $4 \mathrm{ml}$ of the microalgal suspension was filled into $5 \mathrm{ml}$ quartz cuvettes for measurements in the Water-PAM. PS II maximum efficiency $\left(F_{\mathrm{v}} / F_{\mathrm{m}}\right)$ was measured after 3 min dark incubation to determine changes in the photosynthetic efficiency. Prior to dark adaptation, the samples were exposed for $5 \mathrm{~s}$ to weak, far-red light.

The photoadaptive index was estimated from a photosynthesis (in terms of relative electron transport rate, $\mathrm{rETR}=\mathrm{PFR} \times \Delta F / F_{\mathrm{m}}{ }^{\prime} ;$ PFR: photon fluence rate) versus irradiance curve ( $P-E$ curve). $P-E$ curves were measured for every replicate $(\mathrm{n}=3$, chosen at random from the 5 replicates) using 8 actinic light intensities $(17,26$, 38, 58, 87, 128, 198 and $294 \mu \mathrm{mol}$ photons $\mathrm{m}^{-2} \mathrm{~s}^{-1}$ ) as described by Roleda et al. (2006). The hyperbolic tangent model of Jassby \& Platt (1976) was used to estimate $P-E$ curve parameters described as:

$$
\mathrm{rETR}=\mathrm{rETR}_{\max } \times \tan h\left(\alpha \times E_{\mathrm{PAR}} \mathrm{rETR}_{\max }{ }^{-1}\right)
$$

where $\mathrm{rETR}_{\max }$ is the maximum relative electron transport rate, $\tan h$ is the hyperbolic tangent function, $\alpha$ is the electron transport efficiency and $E_{\mathrm{PAR}}$ is the PFR of PAR. The saturation irradiance for electron transport $\left(E_{\mathrm{k}}\right)$ was calculated as the light intensity at which the initial slope of the curve $(\alpha)$ intercepts the horizontal asymptote $\left(\mathrm{rETR}_{\max }\right)$. Data from the triplicates of each treatment were plotted together, and a single curve fit for each treatment was calculated with the Solver Module of MS-Excel using the least-squares method comparing differences between measured and calculated data. The fitness $\left(\mathrm{R}^{2}\right)$ of the curves was tested using regression analysis $(p=0.05)$. The saturating photosynthetic photon flux density (PPDF) value, at which photosynthesis is at $95 \%$ of the maximum value, $\left(E_{0.95}\right)$ is directly proportional to $E_{\mathrm{k}}$ and can be derived using the equation $E_{0.95}=\tanh ^{-1}$ (0.95) $E_{\mathrm{k}}$ (Chalker et al. 1983) (Table 2).

Photosynthetic pigments. After 4, 8 and $16 \mathrm{~h}$ exposure to different radiation treatments and $24 \mathrm{~h}$ under

Table 1. Total intensities and doses of different radiation treatments for the 4, 8, and $16 \mathrm{~h}$ experimental periods. For UV-B, filtered and non-filtered intensities (with and without a Schott WG 320 filter) are shown

\begin{tabular}{|c|c|c|c|c|c|}
\hline Treatment & $\begin{array}{c}\text { PAR } \\
(\mu \mathrm{mol} \text { photons } \\
\left.\mathrm{m}^{-2} \mathrm{~s}^{-1}\right)\end{array}$ & $\begin{array}{c}\mathrm{UV}-\mathrm{A} \\
\left(\mathrm{W} \mathrm{m}^{-2}\right)\end{array}$ & $\begin{array}{c}\text { Dose } \\
\text { UV-A } \\
\text { (kJ 4/8/16 h) }\end{array}$ & $\begin{array}{c}\mathrm{UV}-\mathrm{B} \\
\text { (W m }{ }^{-2}, \\
\text { filtered/unfiltered) }\end{array}$ & $\begin{array}{c}\text { Dose } \\
\text { UV-B } \\
\text { (kJ 4/8/16 h) }\end{array}$ \\
\hline $\mathrm{PAR}+\mathrm{UV}-\mathrm{A}+\mathrm{UV}-\mathrm{B}(\mathrm{PAB})$ & 44 & 9.05 & $130 / 261 / 521$ & $0.7 / 0.9$ & $10 / 20 / 40,13 / 26 / 52$ \\
\hline PAR + UV-A (PA) & 44 & 8.90 & $128 / 256 / 513$ & $0.06 / 0.08$ & $\begin{array}{l}0.9 / 1.7 / 3.5 \\
1.2 / 2.2 / 4.5\end{array}$ \\
\hline PAR (P) & 44 & 0.08 & $1.2 / 2.3 / 4.6$ & $0.01 / 0.01$ & $\begin{array}{l}0.1 / 0.3 / 0.6 \\
0.3 / 0.4 / 0.8\end{array}$ \\
\hline Recovery PAR & $<10$ & 0 & 0 & 0 & 0 \\
\hline
\end{tabular}


Table 2. Photosynthesis-irradiance response $(P-E)$ curve parameter estimates in controls and after $8 \mathrm{~h}$ radiation exposure, using the hyperbolic tangent equation of Jassby \& Platt (1976) and Chalker et al. (1983). Radiation treatments are PAR + UV-A + UV-B (PAB), PAR + UV-A (PA) and PAR (P). ETR $_{\text {max }}$ : relative electron transport rate, $\alpha$ : electron transport efficiency, $E_{\mathrm{k}}$ : light intensity at which the initial slope of the curve $(\alpha)$ intercepts the horizontal asymptote, the maximum relative electron transport rate $\left(\mathrm{rETR}_{\max }\right) ; E_{0.95}$ : saturating photosynthetic photon flux density value at which photosynthesis is at $95 \%$ of the maximum value $\left[E_{0.95}=\tan h^{-1}\right.$ (0.95) $\left.E_{\mathrm{k}}\right]_{;} \mathrm{R}^{2}$ : fitness of the hyperbolic tangent curve

\begin{tabular}{|lccccc|}
\hline & ETR $_{\max }$ & $\alpha$ & $E_{\mathrm{k}}$ & $E_{0.95}$ & $\mathrm{R}^{2}$ \\
\hline Control & 8.4 & 0.127 & 66.1 & 121.0 & 0.99 \\
8 h P & 10.1 & 0.142 & 71.3 & 130.7 & 0.95 \\
8 h PA & 8.4 & 0.127 & 65.8 & 120.5 & 0.94 \\
8 h PAB & 7.2 & 0.109 & 66.4 & 121.7 & 0.96 \\
\hline
\end{tabular}

recovery radiation, the contents of each Petri dish were filtered onto $25 \mathrm{~mm}$ Whatman GF/F filters, giving 72 filters plus 4 from the initial control treatment (in total 76 filters). The filters were blotted, folded and put in liquid nitrogen $\left(-196^{\circ} \mathrm{C}\right)$ and transferred to $-80^{\circ} \mathrm{C}$. After ca. $3 \mathrm{mo}$, the filters were transported frozen $\left(-20^{\circ} \mathrm{C}\right)$ to Sweden, again stored in $-80^{\circ} \mathrm{C}$ and analyzed within 2 mo. Pigment extraction and analysis was done according to Wright \& Jeffrey (1997). The pigments were extracted in $1.5 \mathrm{ml}$ acetone:MeOH $(80: 20)$ for $24 \mathrm{~h}$ in $-20^{\circ} \mathrm{C}$. The extract was then sonicated for $30 \mathrm{~s}$ using a Vibra-cell sonicator equipped with a $3 \mathrm{~mm}$ diameter probe and diluted with $100 \% \mathrm{MeOH} 1: 2$ or 1:3. HPLC (high-performance liquid chromatography)-analysis was carried out using an absorbance diode-array detector (Spectraphysics UV6000LP). A C18 Phenomenex Ultracarb $3 \mu \mathrm{m}$ ODS $(20)(150 \times 3.20 \mathrm{~mm})$ column and a guard column, SecurityGuard Phenomenex C18 $(4 \times$ $3.0 \mathrm{~mm}$ ), were used. The HPLC system was calibrated with pigment standards from DHI, Water and Environment, Denmark. Peak identities were further confirmed by on-line recording of absorbance spectra (400 to $700 \mathrm{~nm}$ ) as described in Wright \& Jeffrey (1997). Dominating pigments detected were chlorophyll $C_{1} C_{2}$, fucoxanthin (fucox), a fucoxanthin derivative, diadinoxanthin (Dd), diatoxanthin (Dt), chlorophyll a (chl a) and betacarotene. Pigments are expressed as milligrams per square meter.

DNA damage. DNA damage and its subsequent repair were determined in the semi-natural diatom community after exposure for 4,8 and $16 \mathrm{~h}$ to PAB. For each treatment, 6 experimental units were prepared. After exposure, 3 experimental units were processed immediately, while the other 3 were transferred to low white light for a $24 \mathrm{~h}$ recovery period. Diatoms were suspended from the sand as described above. Sand grains were allowed to settle for a few minutes, and cells in the suspension were decanted and filtered through $44 \mathrm{~mm}$ diameter, $1 \mathrm{~mm}$ pore size Nuclepore polycarbonate membrane. Filters were then placed separately into $2 \mathrm{ml}$ Eppendorf tubes and frozen at $-80^{\circ} \mathrm{C}$ for further analysis.

For DNA extraction, the frozen filters were incubated in cetyltrimethyl ammonium bromide (CTAB) extraction buffer, as described by van de Poll et al. (2001) and modified by Roleda et al. (2004). After extraction, the DNA pellet obtained was dissolved in $200 \mu \mathrm{l}$ TE buffer (10 mM Tris, 1 mM EDTA, pH 8.0), treated with RNAase $\left(5 \mathrm{ml}\right.$ of $10 \mathrm{mg} \mathrm{ml}^{-1}, 30 \mathrm{~min}, 37^{\circ} \mathrm{C}_{\text {; }}$ Sigma) and stored at $-20^{\circ} \mathrm{C}$. The DNA concentration was quantified fluorometrically using the PicoGreen assay (Molecular Probes) and a Cary Eclipse Fluorescence Spectrophotometer (Variance Scientific 12 Instrument). For calibration, a dilution series with a known amount of DNA (Serva) was used.

DNA lesions measured as cyclobutane pyrimidine dimers (CPDs) were determined using an immunoassay described by van de Poll et al. (2001). Heatdenatured samples containing 50 ng DNA were transferred onto a nitrocellulose membrane (Protran BA 79, pore size $0.1 \mathrm{~mm}$; Schleicher and Schuell) with a Minifold I SRC96 dot blot apparatus (Schleicher and Schuell). After a 2-step antibody assay, the membrane was treated with ECL Western blotting detection reagent (Amersham) and sealed in a transparent plastic folder. Subsequently, the films were exposed to photosensitive ECL films (Amersham) at different exposure times and then developed using X-ray film developer (Kodak). Developed films were scanned using a Biorad imaging densitometer (Model GS-700; Bio-Rad). Quantification of the grey-scale values was done by use of Multi-Analyst (Bio-Rad). A calibration series of UV-irradiated calf thymus DNA (Serva), supplemented with unexposed DNA, was included, giving $1 \mu \mathrm{g} \mathrm{ml}^{-1}$ DNA for each calibration point. The UV-irradiated DNA (45 min exposure to 2 TL-20W/12 lamps; Philips) was previously calibrated against UV-irradiated Hela DNA with known amounts of CPDs (kindly provided by A. Vink). CPDs were quantified by comparing the grey scales within the linear range of the film.

Statistical analyses. One-way ANOVA was used to test for the effects of UVR on photosynthetic efficiency, photosynthetic pigments and DNA damage, and the level of significance was set at $p<0.05$. Prior to analysis, data were tested for homogeneity of variances (Cochran's test).

\section{RESULTS}

Initial cell density was $1.4 \times 10^{7}\left( \pm 1.2 \times 10^{6}\right)$ cells $\mathrm{m}^{-2}$. Assuming that all cells belonged to the largest cell size 
measured and exposed the largest possible area upwards, the cells covered $<5 \%$ of the area of the Petri dish (cf. Al-Handal \& Wulff 2008). In all experiments, the most frequently observed $(>50 \%$ ) species were Pleurosigma obscurum Smith and Gyrosigma fasciola (Ehrenberg) Griffith \& Henfrey. Less frequently occurring (10 to $50 \%$ ) species/genera were Entomoneis kjellmannii (Cleve) Poulin et Cardinal, Licmophora antarctica Peragallo, Trachyneis aspera var. aspera (Ehrenberg) Cleve, Amphora sp., Cocconeis costata Gregory var. costata, C. costata var. antarctica Manguin, C. shuettii Gregory, C. pinnata Gregory ex Greville, Navicula cancellata Donkin, N. directa (Smith) Ralfs, Parlibellus delongei (Van Heurck) Cox, Pinnularia quadratarea (Schmidt) Cleve, Navicula cancellata Donkin, Cylindrotheca closterium (Ehrenberg) Lewin \& Reimann, and Petroneis plagiostoma (Grunow) Mann.

\section{General photosynthetic performance}

Parameter estimates obtained from the rapid $P-E$ curves of the diatom community (Fig. 1, Table 2) showed treatment effects on community photosynthesis. The highest $\mathrm{ETR}_{\max }$ was observed after $8 \mathrm{~h}$ treat-
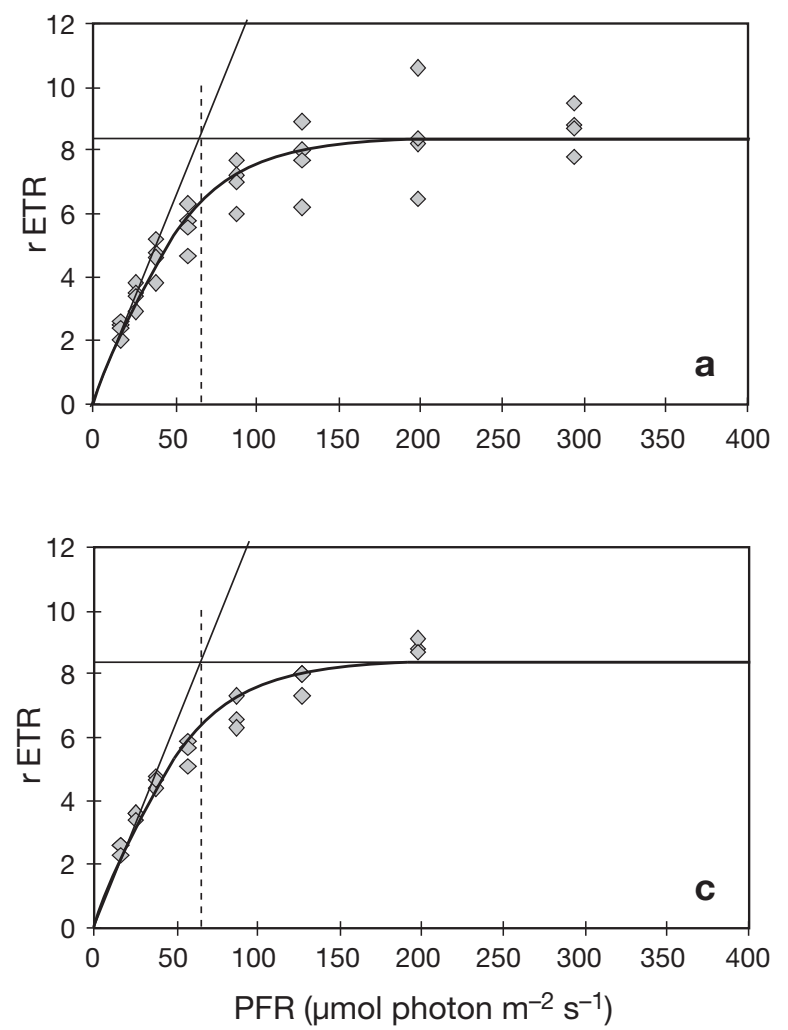

ment with $\mathrm{P}$ alone, and decreased with $\mathrm{PA}$ and PAB treatments. Values for $\alpha$ were also observed to be lower under PAB and PA treatments compared to $\mathrm{P}$ treatments (Table 2). Photosynthesis was already saturated at 66 to $71 \mu \mathrm{mol}$ photons $\mathrm{m}^{-2} \mathrm{~s}^{-1}$, but no photoinhibition was observed up to the highest actinic light treatment $\left(\sim 300 \mu \mathrm{mol}\right.$ photons $\left.\mathrm{m}^{-2} \mathrm{~s}^{-1}\right)$. Photosynthetic capacity $\left(\mathrm{ETR}_{\max }\right.$ and $\left.\alpha\right)$ increased under higher PAR treatment $\left(40 \mu \mathrm{mol}\right.$ photons $\left.\mathrm{m}^{-2} \mathrm{~s}^{-1}\right)$ compared to the control, which was maintained under low PAR conditions $\left(<10 \mu \mathrm{mol}\right.$ photons $\left.\mathrm{m}^{-2} \mathrm{~s}^{-1}\right)$ (Fig. 3, Table 2).

\section{UV treatment effects}

Photosynthesis

Compared with initial samples, $F_{\mathrm{v}} / F_{\mathrm{m}}$ decreased after $8 \mathrm{~h}$ exposure to different radiation treatments. A significantly reduced $F_{\mathrm{v}} / F_{\mathrm{m}}$ was observed between: $\mathrm{PAB}$ and PA, PAB and $\mathrm{P}$, and PA and P (Fig. 2). After $6 \mathrm{~h}$ recovery under dim white light, no significant differences were observed between $\mathrm{PAB}$ and PA, PA and $\mathrm{P}$, but $\mathrm{PAB}$ was significantly higher than $\mathrm{P}$.
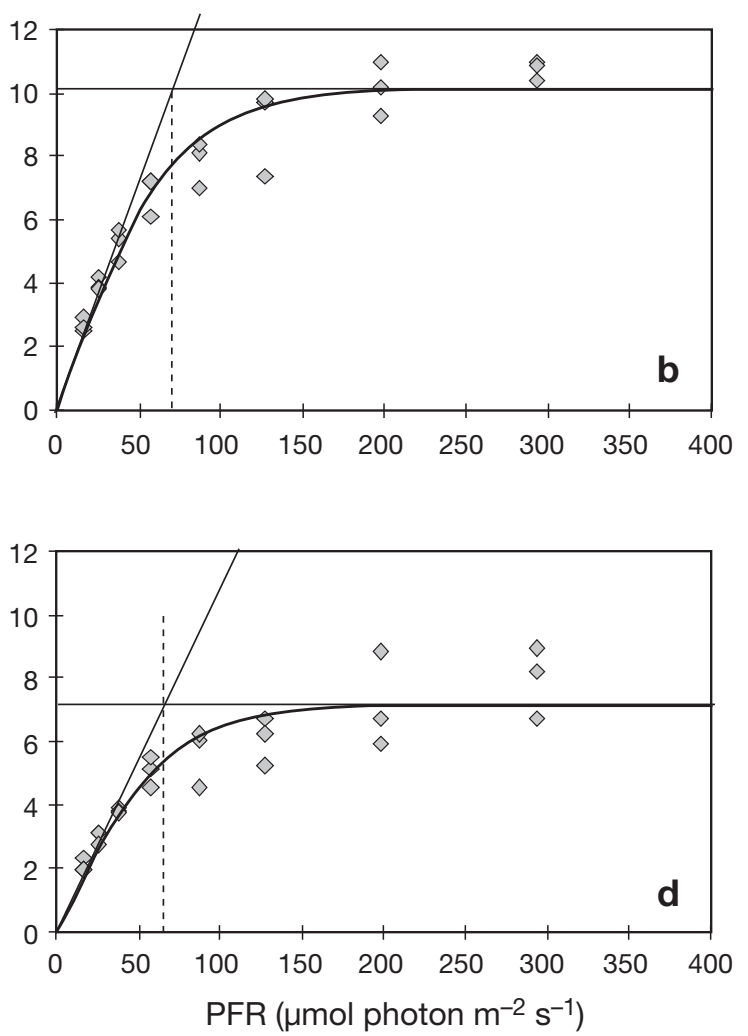

Fig. 1. Photosynthetic performance of the benthic diatom community. Photosynthesis-irradiance $(P-E)$ curves: (a) before exposure (control) and after $8 \mathrm{~h}$ exposure to (b) PAR, (c) PAR + UV-A and (d) PAR + UV-A + UV-B. PFR: photon fluence rate of actinic white light; rETR: relative electron transport rate. Saturating irradiance ( $E_{\mathrm{k}}$, vertical broken lines) is the point at which the initial slope ( $\alpha$ : electron transport efficiency) crosses maximum photosynthesis $\left(\mathrm{rETR}_{\max }\right)$ using a hyperbolic tangent model 


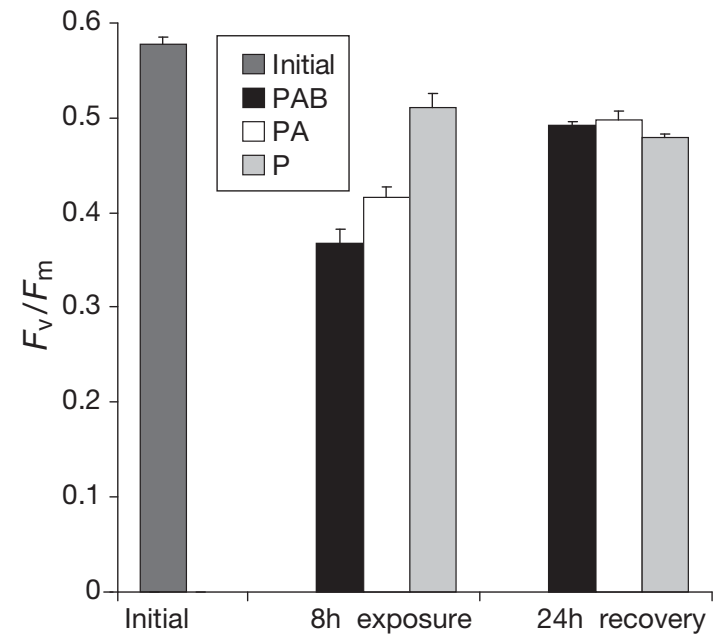

Fig. 2. Photosystem II (PS II) maximum efficiency $\left(F_{\mathrm{v}} / F_{\mathrm{m}}\right)$ after exposure to different radiation treatments $( \pm S E, n=5)$. $P A B$ : PAR + UV-A + UV-B, PA: PAR + UV-A and P: PAR only. Initial: measurements before the different radiation treatments started; $8 \mathrm{~h}$ exposure: measurement after $8 \mathrm{~h}$ exposure; $24 \mathrm{~h}$ recovery: recovery under PAR of $<10 \mu \mathrm{mol}$ photons $\mathrm{m}^{-2} \mathrm{~s}^{-1}$ for $24 \mathrm{~h}$

\section{Photosynthetic pigments}

The most pronounced effects were found for the lightprotective pigments in the xanthophyll cycle, Dt and Dd. There was a dose-dependent accumulation of Dt in the $\mathrm{P}$ and PA treatments, but not in the PAB treatment. Relative to the initial, the ratio increased from ca. 0.07 to $0.13-0.31$ in the different radiation treatments. Significant treatment effects were found between the initial ratio and the $\mathrm{PAB}, \mathrm{PA}$ and $\mathrm{P}$ treatments, respectively (Fig. 3). Within the 4 and $8 \mathrm{~h}$ radiation treatments, no significant effects were observed. Within the $16 \mathrm{~h}$ exposure time, however, significant treatment effects were observed, following the pattern $\mathrm{PAB}<\mathrm{PA}$

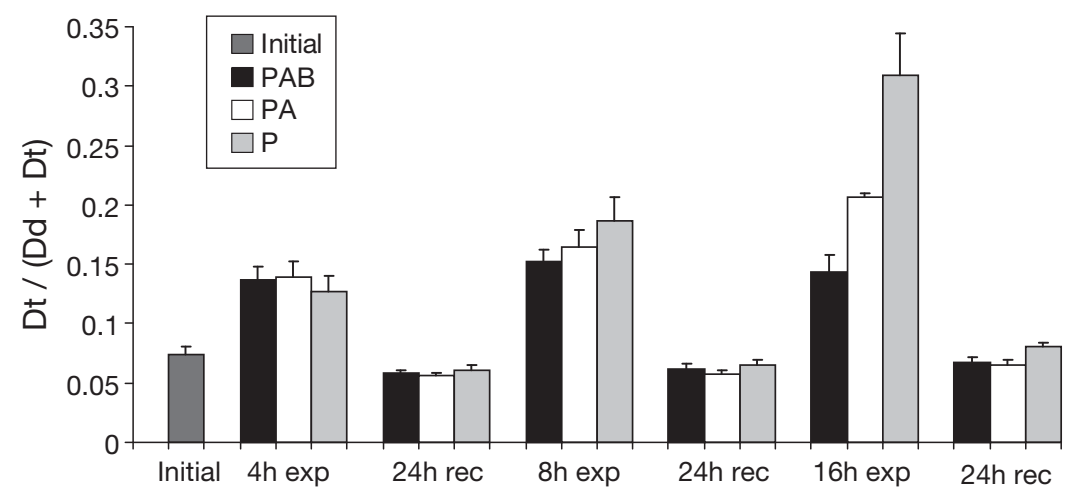

Fig. 3. Ratios between the xanthophyll pool (diatoxanthin [Dt], diadinoxanthin [Dd]) relative to light-harvesting pigments (fucoxanthin, chl a) for the different radiation treatments and their corresponding recovery treatments $(+\mathrm{SE}, \mathrm{n}=4)$. $4 \mathrm{~h}$ exp, $8 \mathrm{~h}$ exp, $16 \mathrm{~h}$ exp: length of radiation exposure; rec: $24 \mathrm{~h}$ under recovery PAR of $<10 \mu \mathrm{mol}$ photons $\mathrm{m}^{-2} \mathrm{~s}^{-1}$; PAB: PAR + UV-A + UV-B; PA: PAR + UV-A; P: PAR only
$<$ P. In addition, significantly lower ratios were found between the recovery values and their respective radiation treatment (Fig. 3). For chl $c_{1} C_{2}$, no apparent trends were observed. Fucoxanthin generally decreased during recovery following 8 and $16 \mathrm{~h}$ exposure to $\mathrm{PAB}, \mathrm{PA}$ and P. A similar tendency was observed for chl $a$ and betacarotene (Table 3).

Considering the $\mathrm{Dd}+\mathrm{Dt}$ pool relative to lightharvesting pigments (fucox, chl a), no significant differences were found between the treatments within the 4 and $8 \mathrm{~h}$ radiation exposure times (Fig. 4). A tendency of increasing ratios with exposure time was observed, but was not related to the UV treatments, except for PA $(8 \mathrm{~h}<16 \mathrm{~h})$. For recovery radiation, the ratio was stable (all treatments; Fig. 4).

\section{DNA}

The amount of DNA lesions measured as CPDs among the different microphytobenthic species composing the semi-natural diatom community increased with increasing UV-B dose (Fig. 5), but no statistically significant differences were found $(4 \mathrm{~h}<16 \mathrm{~h}, \mathrm{p}=0.055)$. After $24 \mathrm{~h}$ under low white light, no CPDs were detected, indicating a complete recovery from DNA damage.

\section{DISCUSSION}

In the study area, ca. $20 \%$ of the incoming UV-B radiation reached $5 \mathrm{~m}$ water depth, and the daily dose reaching the subtidal microalgal community was $3.6 \mathrm{~kJ}$ during the experimental period. In our experiment, the microalgae were exposed to $26 \mathrm{~kJ}$ over the $8 \mathrm{~h}$ exposure time, which is ca. 7 times higher than the actual daily UV-B dose received at $5 \mathrm{~m}$ depth. The daily UV-A dose in our experiment ( $267 \mathrm{~kJ}$ ) was 2.5 times higher than the actual UV-A dose received at $5 \mathrm{~m}$ depth. Together with the low PAR dose, the ratio between PAR/UV-A/UV-B differed from that under natural conditions. Thus, the study was not designed to perfectly mimic natural conditions and should, according to applied radiation treatments, be considered to be mechanistic. However, if anything, we exaggerated the effects of UVR in general, and in particular the effects of UV-B (intensity and dose).

Although the benthic diatoms in our study were exposed to unnaturally high doses of UVR, they were quite resilient to its negative effects. Due to the thin sediment layer and the low cell numbers in each Petri dish, the diatom assemblage 
Table 3. Pigment concentrations $\left(\mathrm{mg} \mathrm{m}^{-2}\right)$ in different treatments $( \pm \mathrm{SE}, \mathrm{n}=4)$. Pigments shown are chlorophyll $c_{1}+C_{2}\left(\right.$ chl $\left.c_{1} C_{2}\right)$, fucoxanthin (fucox), diadinoxanthin (diadinox), diatoxanthin (diatox), chl a and betacarotene (betacar). Radiation treatments are PAB: PAR + UV-A + UV-B, PA: PAR + UV-A and P: PAR. 4h, 8h, 16h: length of exposure, rec: $24 \mathrm{~h}$ under recovery PAR of $<10 \mu \mathrm{mol}$ photons $\mathrm{m}^{-2} \mathrm{~s}^{-1}$

\begin{tabular}{|c|c|c|c|c|c|c|}
\hline Exposure sequence & $\operatorname{chl} C_{1} C_{2}$ & fucox & diadinox & diatox & $\operatorname{chl} a$ & betacar \\
\hline Initial & $0.31( \pm 0.09)$ & $6.95( \pm 1.17)$ & $0.66( \pm 0.12)$ & $0.05( \pm 0.01)$ & $7.27( \pm 1.55)$ & $0.37( \pm 0.07)$ \\
\hline $4 \mathrm{~h}$ PAB & $0.32( \pm 0.19)$ & $4.11( \pm 0.67)$ & $0.45( \pm 0.07)$ & $0.07( \pm 0.01)$ & $6.87( \pm 0.66)$ & $0.24( \pm 0.04)$ \\
\hline $24 \mathrm{~h} \mathrm{rec}$ & $0.29( \pm 0.08)$ & $4.51( \pm 0.72)$ & $0.53( \pm 0.06)$ & $0.03( \pm 0.00)$ & $6.60( \pm 0.32)$ & $0.26( \pm 0.03)$ \\
\hline $4 \mathrm{~h} \mathrm{PA}$ & $0.31( \pm 0.07)$ & $5.57( \pm 0.68)$ & $0.60( \pm 0.07)$ & $0.10( \pm 0.01)$ & $7.52( \pm 0.37)$ & $0.31( \pm 0.04)$ \\
\hline $24 \mathrm{~h} \mathrm{rec}$ & $0.36( \pm 0.14)$ & $6.14( \pm 0.51)$ & $0.66( \pm 0.06)$ & $0.04( \pm 0.00)$ & $7.71( \pm 0.33)$ & $0.32( \pm 0.03)$ \\
\hline $4 \mathrm{~h} \mathrm{P}$ & $0.32( \pm 0.07)$ & $4.06( \pm 0.56)$ & $0.48( \pm 0.04)$ & $0.07( \pm 0.01)$ & $6.76( \pm 0.53)$ & $0.26( \pm 0.02)$ \\
\hline $24 \mathrm{~h}$ rec & $0.28( \pm 0.09)$ & $3.81( \pm 0.49)$ & $0.48( \pm 0.06)$ & $0.03( \pm 0.00)$ & $6.61( \pm 0.62)$ & $0.23( \pm 0.03)$ \\
\hline $8 \mathrm{~h} \mathrm{PAB}$ & $0.26( \pm 0.12)$ & $4.65( \pm 0.47)$ & $0.54( \pm 0.05)$ & $0.10( \pm 0.01)$ & $6.63( \pm 0.16)$ & $0.24( \pm 0.02)$ \\
\hline $24 \mathrm{~h} \mathrm{rec}$ & $0.25( \pm 0.08)$ & $3.25( \pm 0.30)$ & $0.39( \pm 0.03)$ & $0.03( \pm 0.00)$ & $5.73( \pm 0.50)$ & $0.17( \pm 0.02)$ \\
\hline $8 \mathrm{~h} \mathrm{PA}$ & $0.18( \pm 0.05)$ & $4.74( \pm 0.49)$ & $0.57( \pm 0.04)$ & $0.12( \pm 0.02)$ & $7.08( \pm 0.28)$ & $0.25( \pm 0.01)$ \\
\hline $24 \mathrm{~h} \mathrm{rec}$ & $0.24( \pm 0.09)$ & $3.39( \pm 0.77)$ & $0.42( \pm 0.09)$ & $0.03( \pm 0.01)$ & $5.52( \pm 1.00)$ & $0.17( \pm 0.04)$ \\
\hline $8 \mathrm{~h} \mathrm{P}$ & $0.23( \pm 0.08)$ & $3.77( \pm 0.45)$ & $0.48( \pm 0.05)$ & $0.11( \pm 0.02)$ & $6.38( \pm 0.40)$ & $0.24( \pm 0.02)$ \\
\hline $24 \mathrm{~h} \mathrm{rec}$ & $0.22( \pm 0.10)$ & $3.36( \pm 0.41)$ & $0.40( \pm 0.04)$ & $0.03( \pm 0.00)$ & $5.65( \pm 0.52)$ & $0.19( \pm 0.02)$ \\
\hline $16 \mathrm{~h}$ PAB & $0.23( \pm 0.09)$ & $4.02( \pm 0.37)$ & $0.55( \pm 0.05)$ & $0.09( \pm 0.01)$ & $6.03( \pm 0.17)$ & $0.20( \pm 0.02)$ \\
\hline $24 \mathrm{~h} \mathrm{rec}$ & $0.20( \pm 0.05)$ & $2.82( \pm 0.29)$ & $0.34( \pm 0.03)$ & $0.02( \pm 0.00)$ & $4.90( \pm 0.42)$ & $0.13( \pm 0.01)$ \\
\hline $16 \mathrm{~h}$ PA & $0.26( \pm 0.12)$ & $3.70( \pm 0.52)$ & $0.53( \pm 0.06)$ & $0.14( \pm 0.01)$ & $5.63( \pm 0.23)$ & $0.19( \pm 0.02)$ \\
\hline $24 \mathrm{~h} \mathrm{rec}$ & $0.18( \pm 0.05)$ & $3.03( \pm 0.69)$ & $0.37( \pm 0.09)$ & $0.03( \pm 0.01)$ & $5.05( \pm 1.01)$ & $0.14( \pm 0.03)$ \\
\hline $16 \mathrm{~h} P$ & $0.17( \pm 0.03)$ & $4.67( \pm 0.68)$ & $0.57( \pm 0.08)$ & $0.26( \pm 0.05)$ & $6.67( \pm 0.31)$ & $0.26( \pm 0.04)$ \\
\hline $24 \mathrm{~h}$ rec & $0.21( \pm 0.08)$ & $3.47( \pm 0.40)$ & $0.45( \pm 0.06)$ & $0.04( \pm 0.01)$ & $5.83( \pm 0.46)$ & $0.18( \pm 0.02)$ \\
\hline
\end{tabular}

was negatively affected during exposure to UVR. Regardless of the protection strategies such as avoidance, photochemical quenching and repair occurring during exposure treatment within the semi-natural habitat, a net negative UVR effect was measured. The negative effects were, however, observed to be transient. Photosynthetic function was restored, and DNA damage was repaired when UVR was removed. Vertical migration has been suggested to be a key mechanism for epipelic benthic diatoms to avoid UV-B radiation (Underwood et al. 1999, Waring et al. 2007). For example, the epipelic diatom Gyrosigma balticum (Ehrenberg) Rabenhorst responded to UV-B radiation by vertical migration, but a significant UV-B effect on

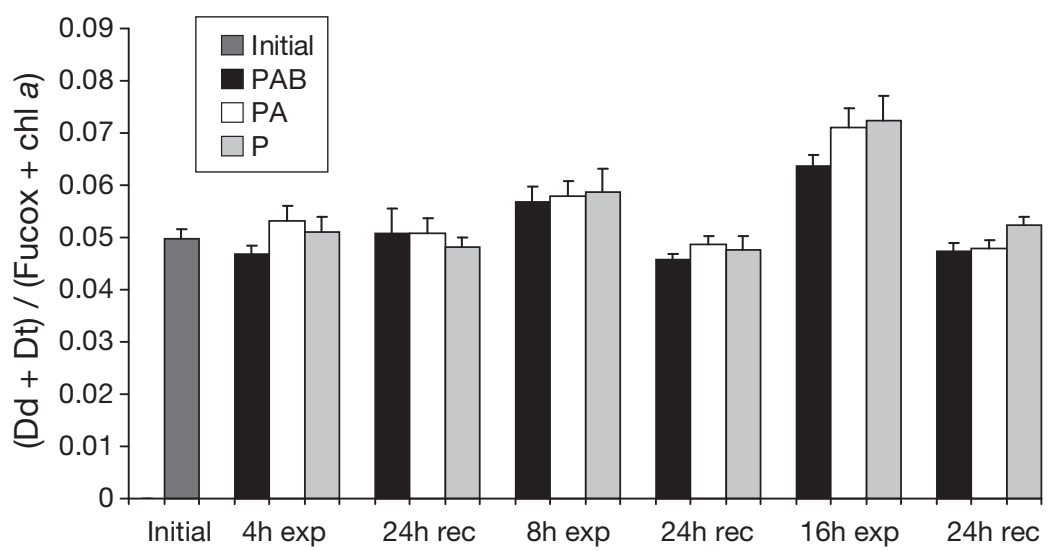

Fig. 4. Ratios of the light-protective xanthophyll pigments diadinoxanthin (Dd) to diatoxanthin $(\mathrm{Dt})$ (weight/weight) $( \pm \mathrm{SE}, \mathrm{n}=4)$; exp: length of radiation exposure; rec: $24 \mathrm{~h}$ under recovery PAR of $<10 \mu \mathrm{mol}$ photons $\mathrm{m}^{-2} \mathrm{~s}^{-1}$; PAB: PAR + UV-A + UV-B; PA: PAR + UV-A; P: PAR only
PS II was still apparent after $5 \mathrm{~d}$ of repeated UV-B exposure (Underwood et al. 1999). Waring et al. (2007) measured UV-B effects on intertidal benthic microalgae in a greenhouse with supplementary UVR, and their data indicated a UV-B-related migratory response independent of ambient PAR. In order to trace UV effects on motile diatoms, it is important to take the sediment depth into account. UV-A has been shown to penetrate $1 \mathrm{~mm}$ into sandy sediment, and UV-B, to $0.6 \mathrm{~mm}$ sediment depth (Wulff et al. 1999). Our set-up was designed to minimize the possibility for the diatoms to move away from the radiation treatments $(<0.7 \mathrm{~mm}$ layer in our set-up). Although vertical migration cannot be excluded within the thin sand layer, the UV treatment effects found in $F_{\mathrm{v}} / F_{\mathrm{m}}$ and the response of the xanthophyll cycle pigments showed that the diatom cells responded to the different radiation treatments. Another strategy to further reduce damaging effects of excessive light energy is to expose the smallest possible surface towards the radiation source. For example, the epipelic diatom Gyrosigma balticum has been found to be oriented perpendicular to the sediment surface with their long axes, and it has been suggested that an upright position may be common among epipelic diatoms (Jönsson et al. 1994). In this context, the most frequently observed cells in the present study belonged to the genera Gyrosigma and Pleurosigma, which have an elongated shape. 


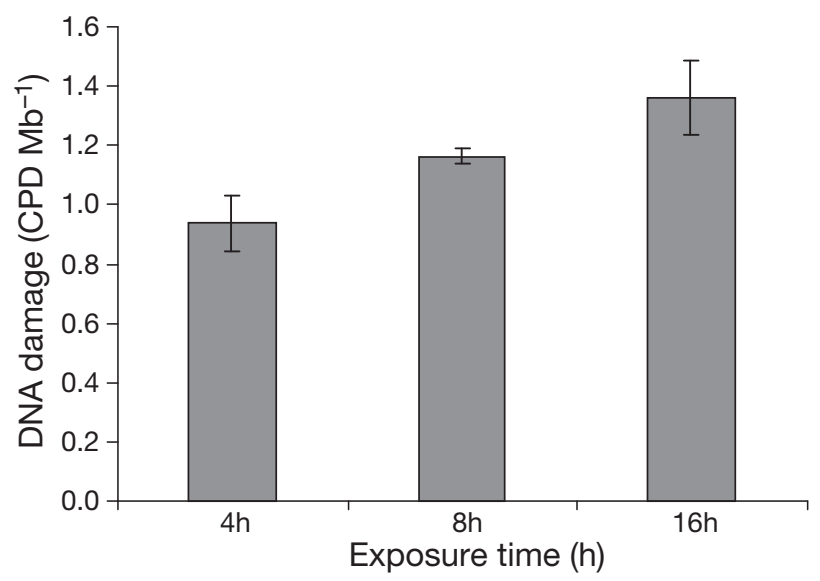

Fig. 5. Amount of DNA lesions measured as cyclobutane pyrimidine dimers (CPDs) after different length of exposure (h) with PAR + UV-A + UV-B $( \pm \mathrm{SE}, \mathrm{n}=3)$

UV effects on microalgae are often species-specific (e.g. Karentz et al. 1991, Neale et al. 1998, Wulff et al. 2000, van de Poll et al. 2006), and some species get more negatively affected than others (van de Poll et al. 2006, Waring et al. 2006). In an earlier study, we observed a shift in the benthic diatom community over 16 and $13 \mathrm{~d}$ experimental periods, respectively, although no significant shifts in species composition between the radiation treatments (PAB vs. PA and PAB vs. P) could be detected (Wulff et al. 2008). The time scale in the present study was too short to elucidate any changes in species composition; however, it is possible that some UV-tolerant species remained on the upper stratum of the $0.7 \mathrm{~mm}$ layer, while UV-sensitive species migrated deeper down (cf. Waring et al. 2007).

\section{UV treatment effects}

\section{Photosynthesis}

PAR supplemented with UV-A had a significant additional effect on the photoinhibition of photosynthesis. The cumulative effects of UV-A + UV-B after $8 \mathrm{~h}$ exposure further reduced $F_{\mathrm{v}} / F_{\mathrm{m}}$ relative to $\mathrm{P}$ and PA treatments. The reduction in $F_{\mathrm{v}} / F_{\mathrm{m}}$ under PAR treatment was not solely due to the photon fluence rate $(E=$ $44 \mu \mathrm{mol}$ photons $\mathrm{m}^{-2} \mathrm{~s}^{-1}$ ), which was lower than the extrapolated $E_{\mathrm{k}}$ (66 to $71 \mu \mathrm{mol}$ photons $\mathrm{m}^{-2} \mathrm{~s}^{-1}$ ), but rather due to the long irradiation period, i.e. the total fluence of PAR applied. In a repeated time series measurement of photosynthetic response to UVR, Waring et al. (2006) reported a reduction in UV-B-induced photoinhibition with increasing UV-B exposure period. They speculated about a possible recovery process or an acclimation to UV-B taking place within the expo- sure period. In high-light-acclimated cells of the planktonic diatom Thalassiosira antarctica Comber, photoinhibition after exposure to $30 \mathrm{~min}$ of $0.6 \mathrm{~W} \mathrm{~m}^{-2}$ UV-B and $51 \mathrm{~W} \mathrm{~m}^{-2} \mathrm{UV}-\mathrm{A}$ radiation required a $2 \mathrm{~h}$ recovery period to regain photosynthetic capacity comparable to the initial value (van de Poll et al. 2006). Litchman \& Neale (2005) showed that low-light-grown cultures of the planktonic diatom T. pseudonana were more sensitive to UVR compared to cultures grown in high light. In our study, the diatom community was first acclimated to low PAR intensities of $<10 \mu \mathrm{mol}$ photons $\mathrm{m}^{-2} \mathrm{~s}^{-1}$ (much lower compared to the above-mentioned studies) before exposure to high doses of UVR (as a function of exposure time). Despite this, the assemblage was observed to be UV tolerant. After $6 \mathrm{~h}$ postcultivation in low white light, $F_{\mathrm{v}} / F_{\mathrm{m}}$ was relatively lower compared to the initial value, but a UVR effect was no longer observed. Kinetics of photosynthetic recovery with shorter time intervals are of interest for future studies to determine the relative rate of recovery between PAR- and UVR-treated samples. Furthermore, van de Poll et al. (2006) did not find any UV effects on the diatom xanthophyll cycle, but a large Dd + Dt pool was suggested to protect against UVRinduced PS II damage. Another aspect of handling excessive light energy is the inherent compensatory PS II capacity (increased PS II turnover rate), allowing cells to maintain photosynthesis in the presence of moderate photoinhibition, defined as up to $50 \%$ decrease in the number of functional centers (Behrenfeld et al. 1998, Kaňa et al. 2002).

Further support for UV tolerance of the benthic diatoms studied was shown by Wulff et al. (2008), where a similar diatom community maintained photosynthesis $\left(F_{\mathrm{v}} / F_{\mathrm{m}}\right)$ and growth over 2 experimental periods (16 and $13 \mathrm{~d}$ ) when exposed to UV-B radiation of $4.7 \mathrm{~kJ} \mathrm{~d}^{-1}$. The corresponding maximum dose at the study site (5 m depth) was $3.6 \mathrm{~kJ} \mathrm{~d}^{-1}$. Moreover, under ambient light conditions, no impacts of UVR on the diatom communities studied (species composition, biomass and growth) were found over two 3.5 mo field experiments in the same area (intertidal and subtidal) (Zacher et al. 2007, Campana et al. 2008).

\section{Photosynthetic pigments}

Within 4 and $8 \mathrm{~h}$ exposure times, no significant UV effects on Dt / (Dt $+\mathrm{Dd})$ were found. Within the $16 \mathrm{~h}$ exposure time, however, the ratio was significantly lower in the PAB treatment. This finding was opposite to what was expected. Although the de-epoxidation of Dd to Dt is known to occur in excessive light (PAR) as a protection against photooxidation (Arsalane et al. 1994, van de Poll et al. 2006), the effect of UV-B on the 
de-epoxidation process is not clear. For the pennate diatom Phaeodactylum tricornutum Bohlin, Goss et al. (1999) found an increase in Dt concentration when exposed to UV-B radiation corresponding to a 3 to $15 \%$ decrease in the ozone layer. The UV-B-dependent increase in Dt concentration was correlated with a concomitant enhancement of non-photochemical quenching of chlorophyll fluorescence and a decrease in the quantum efficiency of oxygen evolution, indicating that UV-B induced Dt functions in thermal energy dissipation. Again, in our study, the Dt / (Dt + Dd) was lower in the UV treatments, possibly due to UV-related blocking of the de-epoxidation process, where the applied UV-B was more efficient compared with the UV-A. In pea leaves Pisum sativum, Pfündel et al. (1992) found an UV-B-related inhibition of the deepoxidase of violaxanthin. Sobrino et al. (2005) showed a wavelength-dependent induction of de-epoxidation of violaxanthin in the picoplankter Nannochloropsis gaditana. In Phaeodactylum tricornutum, Mewes \& Richter (2002) showed a reversal of the Dd cycle when high-light-acclimated cells were exposed to supplemental UV-B radiation. It should be noted, however, that our experimental $16 \mathrm{~h}$ exposure for UV-B radiation of $0.7 \mathrm{~W} \mathrm{~m}^{-2}\left(0.9 \mathrm{~W} \mathrm{~m}^{-2}\right)$ is extreme for the subtidal community studied. However, the epoxidation process was functioning, returning the ratio to initial values after $24 \mathrm{~h}$ in weak PAR. The ratio of $\mathrm{Dt} /(\mathrm{Dd}+\mathrm{Dt})$ never exceeded $30 \%$ over the course of the experiment, and therefore it could be argued that the small increase, although statistically significant, could not make more than a minor contribution to the UVR tolerance observed in the benthic diatoms studied.

During acclimation to high irradiance, the ratio between xanthophyll and light-harvesting pigments increases, due to an increased pool of xanthophyll and a decrease in light-harvesting pigments (Demers et al. 1991, Buma et al. 2006). We observed an increased ratio over time, irrespective of radiation treatment, and UVR did not seem to have any additional effects on $(\mathrm{Dt}+\mathrm{Dd}) /(\mathrm{chl} a+$ fucoxanthin $)$. Thus, what we observed was a dose dependency. A similar increase as a response to PAR acclimation was observed for the planktonic Antarctic diatom Chaetoceros dichaeta Ehrenberg (Buma et al. 2006). It should be noted that, probably due to the low light conditions preceding the experiments, the pool of xanthophyll pigments to lightharvesting pigments was very low.

\section{DNA damage}

Accumulation of CPDs can arrest the cell cycle in the DNA synthesis phase and obstruct de novo synthesis of cellular components and substances required for cellu- lar maintenance and growth. Unless DNA damage is repaired, this can eventually lead to cell death. DNA damage can, however, be repaired by photoreactivation controlled by light in the UV-A to PAR region. Photoreactivation has been demonstrated in several marine organisms, including viruses, bacteria and early life stages of macroalgae (Buma et al. 2003, Roleda et al. 2007). In the planktonic Antarctic diatom Chaetoceros dichaeta, no CPD accumulation was detected in high light-acclimated cells exposed to 0.1 $\mathrm{W} \mathrm{m}^{-2} \mathrm{UV}-\mathrm{B}$ for $2 \mathrm{~h}$ (corresponding to $4 \mathrm{~m}$ water depth) (Buma et al. 2006). Exposure to a higher dose of UV-B radiation can inadvertently cause DNA lesion, but the benthic diatoms in our experiment exposed to $0.7 \mathrm{~W}$ $\mathrm{m}^{-2}\left(0.9 \mathrm{~W} \mathrm{~m}^{-2}\right) \mathrm{UV}-\mathrm{B}$ for up to $16 \mathrm{~h}$ sustained only very minimal DNA damage. Furthermore, DNA damage was completely repaired within $24 \mathrm{~h}$ when allowed to recover under photoreactivating light (no shorter recovery times were measured to determine repair kinetics).

Induction and accumulation of CPDs (as a measure of DNA damage) increases not only with increasing UV-B radiation, but is also size-class dependent and species- as well as group-specific. Compared with other microalgae, diatoms were less vulnerable to UV$B$, and the smallest size fraction of plankton was more susceptible to DNA damage (Buma et al. 2001). Aside from the functional relevance of size, susceptibility to DNA damage was related to the presence of photoprotective compounds and the lower effectiveness of the screening pigments in smaller cells (Garcia-Pichel 1994). The minimal DNA damage measured on the diatom community in the present study could be attributed to the dominance of 2 large diatom species (100 to $150 \mu \mathrm{m})$. These large benthic pennate diatom species, however, do not contain any UV-absorbing compounds like mycosporine-like amino acids (Wulff unpubl. data). Thus, other possible UV-protective mechanisms (i.e. the presence of a thick silica cell wall and other accessory pigments) are in operation and responsible for their lower susceptibility of sustaining DNA lesions.

In conclusion, laboratory experiments to describe community dynamics and response to stress factors should be interpreted with great caution. Results of the present study mainly provide valuable information on basic mechanistic physiological responses at the community level. Further studies are needed to elucidate the different mechanisms behind UVR tolerance among various species, which enable the diatom community to maintain their photosynthetic capacity regardless of the relatively high UV doses applied. The xanthophyll pigments clearly increased with radiation dose, but no clear UV effects were found, except for the extreme $16 \mathrm{~h}$ exposure. The DNA repair mechanism was also efficient under unnaturally high UV-B 
doses. According to our results, UVR does not seem to be a threat to benthic marine Antarctic diatoms. However, final determinations of UV effects on natural communities of Antarctic marine benthic microalgae require in situ measurements of all variables tested in the present study.

Acknowledgements. This work was done under the agreement on scientific cooperation between the AWI and DNA at Dallmann Laboratory, annex to Jubany Station. The authors thank A. Y. Al-Handal for help with species identifications, and the German and the Argentine dive crews of Jubany and Dallmann for assistance in the field. We gratefully acknowledge financial support by the Foundation of YMER, Royal Society of Arts and Sciences in Göteborg, Lennander's Foundation, The Längman Cultural Foundation and Helge Ax:son Johnson's Foundation (A.W.), the German Research Council (DFG), and the Alfred Wegener Institute for Polar and Marine Research, Germany.

\section{LITERATURE CITED}

Ahn IY, Chung H, Kang JS, Kang SH (1994) Preliminary studies on the ecology of neritic marine diatoms in Maxwell Bay, King George Island, Antarctica. Korean J Phycol 9: 37-45

- Al-Handal AY, Wulff A (2008) Marine benthic diatoms from Potter Cove, King George Island, Antarctica. Bot Mar 51: $51-68$

Arsalane W, Rousseau B, Duval JC (1994) Influence of the pool size of the xanthophyll cycle on the effects of light stress in a diatom: competition between photoprotection and photoinhibition. Photochem Photobiol 60:237-243

- Behrenfeld MJ, Prasil O, Kolber ZS, Babin M, Falkowski PG (1998) Compensatory changes in Photosystem II electron turnover rates protect photosynthesis from photoinhibition. Photosynth Res 58:259-268

Blanchard GF, Cariou-le Gall V (1994) Photosynthetic characteristics of microphytobenthos in Marennes-Oleron Bay, France: preliminary results. J Exp Mar Biol Ecol 182:1-14

Bothwell ML, Sherbot DMJ, Pollock CM (1994) Ecosystem response to solar ultraviolet-B radiation: influence of trophic-level interactions. Science 265:97-100

Buma AGJ, de Boer MK, Boelen P (2001) Depth distribution of DNA damage on Antarctic marine phyto- and bacterioplankton exposed to summertime UV radiation. J Phycol 37:200-208

Buma AGJ, Boelen P, Jeffrey WH (2003) UVR-induced DNA damage in aquatic organisms. In: Helbling W, Zagarese $\mathrm{H}$ (eds) UV effects in aquatic organisms and ecosystems. The Royal Society of Chemistry, Cambridge, p 291-320

Buma AGJ, Wright SW, van den Enden R, van de Poll WH, Davidson AT (2006) PAR acclimation and UVBR-induced DNA damage in Antarctic marine microalgae. Mar Ecol Prog Ser 315:33-42

Campana GL, Quartino ML, Yousif A, Wulff A (2008) Impacts of UV radiation and grazing on the structure of a subtidal benthic diatom assemblage in Antarctica. Ber Polarforsch 571:302-310

> Chalker BE, Dunlap WC, Oliver JK (1983) Bathymetric adaptations of reef-building corals at Davies Reef, Great Barrier Reef, Australia. II. Light saturation curves for photosynthesis and respiration. J Exp Mar Biol Ecol 73:37-56

Demers S, Roy S, Gagnon R, Vignault C (1991) Rapid light- induced changes in cell fluorescence and in xanthophyllcycle pigments of Alexandrium excavatum (Dinophyceae) and Thalassiosira pseudonana (Bacillariophyceae): a photo-protection mechanism. Mar Ecol Prog Ser 76: 185-193

Demmig-Adams B, Adams WW (1996) The role of xanthophyll cycle carotenoids in the protection of photosynthesis. Trends Plant Sci 1:21-26

Franklin L, Forster RM (1997) The changing irradiance environment: consequences for marine macrophyte physiology, productivity and ecology. Eur J Phycol 32:207-232

Garcia-Pichel F (1994) A model for internal self-shading in planktonic organisms and its implications for the usefulness of ultraviolet sunscreens. Limnol Oceanogr 39: 1704-1717

> Goss R, Mewes H, Wilhelm C (1999) Stimulation of the diadinoxanthin cycle by UV-B radiation in the diatom Phaeodactylum tricornutum. Photosynth Res 59:73-80

Guillard RRL (1975) Culture of phytoplankton for feeding marine invertebrates. In: Smith WL, Chanley MH (eds) Culture of marine invertebrate animals. Plenum Press, New York, p 29-60

> Hendey NI (1951) Littoral diatoms of Chichester Harbour with special reference to fouling. J R Microsc Soc 71:1-86

Hendey NI (1964) An introductory account of the smaller algae of the British coastal waters, 5. Bacillariophyceae (diatoms). Fishery Investigations Series 4, HMSO, London

Hustedt F (1961) Die Kieselalgen Deutschlands, Österreich und der Schweiz unter Berücksichtigung der übrigen Länder Europas sowie der angrenzenden Meeresgebiete. In: Rabenhorst L (ed) Kryptogamen-Flora von Deutschland, Österreich und der Schweiz, Vol. 7, Part 2. Akademische Verlagsgesellschaft, Leipzig

Jassby AD, Platt T (1976) Mathematical formulation of the relationship between photosynthesis and light for phytoplankton. Limnol Oceanogr 21:540-547

Jönsson B, Sundbäck K, Nilsson C (1994) An upright life-form of an epipelic motile diatom: on the behaviour of Gyrosigma balticum. Eur J Phycol 29:11-15

Kaňa R, Lazar D, Prasil O, Naus J (2002) Experimental and theoretical studies on the excess capacity of Photosystem II. Photosynth Res 72:271-284

Karentz D (1994) Ultraviolet tolerance mechanisms in Antarctic marine organisms. Antarct Res Ser 62:93-110

Karentz DK, Cleaver JE, Mitchell DL (1991) Cell survival characteristics and molecular responses of Antarctic phytoplankton to ultraviolet-B radiation. J Phycol 27:326-341

Krammer K, Lange-Bertalot H (1986) Bacillariophyceae, Parts 1-4. In: Ettl H, Gerloff F, Heynig H, Mollenhauer D (eds) Süßwasserflora von Mitteleuropa. Fischer, Stuttgart

Krammer K, Lange-Bertalot H (1988) Bacillariophyceae 2. Teil. Epithemiaceae, Bacillariaceae, Surirellaceae. In: Ettl H, Gerloff F, Heying H, Mollenhauer D (eds) Süßwasserflora von Mitteleuropa 2/2. Gustav Fischer Verlag, Stuttgart, p 1-596

Litchman E, Neale PJ (2005) UV effects on photosynthesis, growth and acclimation of an estuarine diatom and cryptomonad. Mar Ecol Prog Ser 300:53-62

Mewes H, Richter M (2002) Supplementary ultraviolet-B radiation induces a rapid reversal of the diadinoxanthin cycle in the strong light-exposed diatom Phaeodactylum tricornutum. Plant Physiol 130:1527-1535

Neale P, Cullen J, Davis R (1998) Inhibition of marine photosynthesis by ultraviolet radiation: variable sensitivity of phytoplankton in the Weddell-Scotia Confluence during the austral spring. Limnol Oceanogr 43:433-448

Nelson J, Eckman J, Robertson C, Marinelli R, Jahnke R 
(1999) Benthic microalgal biomass and irradiance at the sea floor on the continental shelf of the South Atlantic Bight: spatial and temporal variability and storm effects. Cont Shelf Res 19:477-505

Olaizola M, Yamamoto HY (1994) Short-term response of the diadinoxanthin cycle and fluorescence yield to high irradiance in Chaetoceros muelleri (Bacillariophyceae). J Phycol 30:606-612

Pfündel EE, Pan RS, Dilley RA (1992) Inhibition of violaxanthin deepoxidation by ultraviolet-B radiation in isolated chloroplasts and intact leaves. Plant Physiol 98:1372-1380

Roleda MY, van de Poll WH, Hanelt D, Wiencke C (2004) PAR and UVBR effects on photosynthesis, viability, growth and DNA in different life stages of two coexisting Gigartinales: implications for recruitment and zonation pattern. Mar Ecol Prog Ser 281:37-50

Roleda MY, Hanelt D, Wiencke C (2006) Exposure to ultraviolet radiation delays photosynthetic recovery in Arctic kelp zoospores. Photosynth Res 88:311-322

Roleda MY, Zacher K, Wulff A, Hanelt D, Wiencke C (2007) Photosynthetic performance, DNA damage and repair in gametes of the endemic Antarctic brown alga Ascoseira mirabilis exposed to ultraviolet radiation. Austral Ecol 32: 917-926

Round FE, Crawford RM, Mann DG (1990) The diatoms: biology and morphology of the genera. Cambridge University Press, Cambridge

Roux R, Gosselin M, Desrosiers G, Rozais C (2002) Effects of reduced UV radiation on a microbenthic community during a microcosm experiment. Mar Ecol Prog Ser 225:29-43

Schloss IR, Ferreyra GA, Curtosi A (1998) Phytoplankton primary production in Potter Cove, King George Island. Report No. 299, Alfred Wegener Institute for Polar and Marine Research, Bremerhaven

Sobrino C, Neale PJ, Montero O, Lubian LM (2005) Biological weighting function for xanthophyll de-epoxidation induced by ultraviolet radiation. Physiol Plant 125:41-51

Suggett DJ, Oxborough K, Baker NR, MacIntyre HL, Kana TM, Geider RJ (2003) Fast repetition rate and pulse amplitude modulation chlorophyll a fluorescence measurements for assessment of photosynthetic electron transport in marine phytoplankton. Eur J Phycol 38:371-384

Sundbäck K, Odmark S, Wulff A, Nilsson C, Wängberg SA (1997) Effects of enhanced UVB radiation on a marine benthic diatom mat. Mar Biol 128:171-179

Underwood GJC, Kromkamp J (1999) Primary production by phytoplankton and microphytobenthos in estuaries. Adv Ecol Res 29:93-153

Underwood GJC, Nilsson C, Sundback K, Wulff A (1999) Short-term effects of UVB radiation on chlorophyll fluo-

Editorial responsibility: Hans Heinrich Janssen, Oldendorf/Luhe, Germany rescence, biomass, pigments, and carbohydrate fractions in a benthic diatom mat. J Phycol 35:656-666

van de Poll WH, Eggert A, Buma AGJ, Breeman AM (2001) Effects of UV-B-induced DNA damage and photoinhibition of growth of temperate marine red macrophytes: habitat-related differences in UV-B tolerance. J Phycol 37: 30-37

van de Poll WH, Alderkamp AC, Janknegt PJ, Roggeveld J, Buma AGJ (2006) Photoacclimation modulates excessive photosynthetically active and ultraviolet radiation effects in a temperate and an Antarctic marine diatom. Limnol Oceanogr 51:1239-1248

Villafañe V, Sundbäck K, Figueroa F, Helbling W (2003) Photosynthesis in the aquatic environment as affected by UVR. In: Helbling W, Zagarese H (eds) UV effects in aquatic organisms and ecosystems. The Royal Society of Chemistry, Cambridge, p 357-397

- Waring J, Underwood GJC, Baker NR (2006) Impact of elevated UV-B radiation on photosynthetic electron transport, primary productivity and carbon allocation in estuarine epipelic diatoms. Plant Cell Environ 29:521-534

> Waring J, Baker NR, Underwood GJC (2007) Responses of estuarine intertidal microphytobenthic algal assemblages to enhanced ultraviolet B radiation. Glob Change Biol 13:1398-1413

Weatherhead EC, Andersen SB (2006) The search for signs of recovery of the ozone layer. Nature 441:39-45

Witkowski A, Lange-Bertalot H, Metzelin D (2000) Diatom flora of marine coasts. I. Iconographia Diatomologica 7 , Gantner Verlag, Ruggell

Wright SW, Jeffrey SW (1997) High-resolution HPLC system for chlorophylls and carotenoids of marine phytoplankton. In: Jeffrey SW, Mantoura RFC, Wright SW (eds) Phytoplankton pigments in oceanography: guidelines to modern methods. UNESCO, Paris, p 327-342

Wulff A, Nilsson C, Sundbäck K, Wängberg SÅ, Odmark S (1999) UV radiation effects on microbenthos-a four month field experiment. Aquat Microb Ecol 19:269-278

Wulff A, Wängberg SÅ, Sundbäck K, Nilsson C, Underwood GJC (2000) Effects of UVB radiation on a marine microphytobenthic community growing on a sand-substratum under different nutrient conditions. Limnol Oceanogr 45: $1144-1152$

Wulff A, Zacher K, Hanelt D, Al-Handal A, Wiencke C (2008) UV radiation-A threat to Antarctic benthic marine diatoms? Antarct Sci 20:13-20

Zacher K, Hanelt D, Wiencke C, Wulff A (2007) Grazing and UV radiation effects on an Antarctic intertidal microalgal assemblage: a long-term field study. Polar Biol 30: $1203-1212$

Submitted: October 15, 2007; Accepted: June 19, 2008

Proofs received from author(s): July 27, 2008 